\title{
Ultrastructure of the spermatozoon of the digenean Lecithocladium excisum (Rudolphi, 1819) (Hemiuroidea: Hemiuridae), a parasite of marine teleosts in Senegal
}

\author{
Papa Ibnou Ndiaye ${ }^{1}$, Papa Mbagnick Diagne ${ }^{1}$, Aminata Sène ${ }^{1}$, Abdoulaye J.S. Bakhoum ${ }^{2,3}$ and Jordi Miquel Mb $^{2,3}$ \\ ${ }^{1}$ Laboratory of Evolutionary Biology, Ecology and Management of Ecosystems, Faculty of Sciences and Techniques, Cheikh Anta \\ Diop University of Dakar, BP 5055, Dakar, Senegal; \\ ${ }^{2}$ Laboratori de Parasitologia, Departament de Microbiologia i Parasitologia Sanitàries, Facultat de Farmàcia, Universitat de \\ Barcelona, Av. Joan XXIII, s/n, 08028 Barcelona, Spain; \\ ${ }^{3}$ Institut de Recerca de la Biodiversitat, Facultat de Biologia, Universitat de Barcelona, Av. Diagonal, 645, 08028 Barcelona, Spain
}

\begin{abstract}
The present study describes the ultrastructure of the mature spermatozoon of Lecithocladium excisum (Rudolphi, 1819) (Digenea: Hemiuroidea: Hemiuridae) from the stomach of the marine teleost Scomber japonicus Houttuyn (Scombridae) captured in the Atlantic Ocean, off Dakar (Senegal). The ultrastructural organization of the spermatozoon of L. excisum follows the general model described in most digeneans. It presents two axonemes of the $9+$ ' 1 ' pattern of the Trepaxonemata, nucleus, mitochondrion and parallel cortical microtubules, among other characters. However, some particularities of the spermatozoon of $L$. excisum are (i) the presence of a membranous ornamentation not associated with cortical microtubules in its anterior extremity, (ii) the presence of a very reduced number of cortical microtubules located only in the ventral side of the spermatozoon and (iii) the absence of several structures described in most digeneans such as spine-like bodies and cytoplasmic expansions.
\end{abstract}

Keywords: Lecithocladium excisum, Hemiuridae, Digenea, spermatozoon, ultrastructure, Scomber japonicus, Scombridae, fish, Senegal

The hemiuroid trematode Lecithocladium excisum (Rudolphi, 1819) is the type-species of the genus and it is characterized, between other aspects, by the plications of the body surface, well-developed ecsoma, long sinussac and the presence of seven long and tubular vitelline lobes. The genus Lecithocladium Lühe, 1901 includes parasites of the stomach of marine teleost fishes (see Gibson 2002a). It is one of the four genera belonging to the subfamily Elytrophallinae Skrjabin et Guschanskaja, 1954. Within the Hemiuroidea Looss, 1899, the family Hemiuridae Looss, 1899 was erected from the subfamily Hemiurinae Looss, 1899 and, now, this family includes the Elytrophallinae and other 11 subfamilies (see Gibson 2002a,b).

Amount of data on the ultrastructure of spermatozoa of flatworms (Platyhelminthes) has accumulated considerably during last decades (for a review see Justine 2001, Levron et al. 2010). In the case of tapeworms, particularly the eucestodes, several authors have postulated different patterns of spermiogenesis and recently different types of spermatozoa (Świderski 1986, Bâ and Marchand 1995,
Levron et al. 2010). The ultrastructural characters of the spermatozoon are known to be useful when interpreting relationships among Platyhelminthes, especially those among cestodes (Hoberg et al. 1997, 2001, Justine 1998, 2001, Olson et al. 2001, Levron et al. 2010). In fact, despite the numerous studies on digenean spermatozoon ultrastructure, to date the application of these characters for phylogenetic studies is much scarcer in digeneans than in tapeworms. Nevertheless, during the last years, several authors worked in this direction and in the near future the ultrastructural characters of the spermatozoon may become very useful for the interpretation of relationships between the Digenea (see Miquel et al. 2006, Quilichini et al. 2010a,b, 2011, Bakhoum et al. 2011a,b, in press, Ndiaye et al. 2012).

To date, there are no data on the spermatozoon ultrastructure in the family Hemiuridae. The present study on L. excisum is the first approach to the ultrastructural organization of the mature spermatozoon in this family. Our results are particularly compared with the available spermatological data of hemiuroideans. 


\section{MATERIALS AND METHODS}

Live adult specimens of Lecithocladium excisum were collected during April 2011 from the stomach of two marine teleosts, the chub mackerel Scomber japonicus Houttuyn, 1782 (Scombridae) and the false scad Caranx rhonchus Geoffroy Saint-Hilaire, 1817 (Carangidae), both captured in the Atlantic Ocean, off Dakar (Senegal). Voucher specimens as whole mounts stained with Semichon's acetic carmine and mounted in Canada balsam are deposited in the parasitological collection of the Muséum National d'Histoire Naturelle (Paris) (MNHN): one slide of $L$. excisum ex S. japonicus (no. 11042606) off Ouakam (Dakar, Senegal), 26 April 2011 - accession number MNHN HEL253; one slide of L. excisum ex C. rhonchus (no. 11042608) off Soumbédioune (Dakar, Senegal), 26 April 2011 accession number MNHN HEL254.

For the present TEM study, several worms collected from $S$. japonicus were rinsed with a $0.9 \% \mathrm{NaCl}$ solution and fixed in cold $\left(4^{\circ} \mathrm{C}\right) 2.5 \%$ glutaraldehyde in a $0.1 \mathrm{M}$ sodium cacodylate buffer at $\mathrm{pH} 7.4$, rinsed in $0.1 \mathrm{M}$ sodium cacodylate buffer at $\mathrm{pH} 7.4$, post-fixed in cold $\left(4^{\circ} \mathrm{C}\right) 1 \%$ osmium tetroxide with $\mathrm{K}_{4} \mathrm{FeCn}_{6}$ in the same buffer for $1 \mathrm{~h}$, rinsed in a $0.1 \mathrm{M}$ sodium cacodylate buffer at $\mathrm{pH}$ 7.4, dehydrated in an ethanol series and propylene oxide, embedded in Spurr's resin and polymerized at $60^{\circ} \mathrm{C}$ for $72 \mathrm{~h}$.

Ultrathin sections (60-90 nm thick) of seminal ducts and seminal vesicle were obtained using a Reichert-Jung Ultracut E ultramicrotome using a diamond knife. Sections were placed on copper and gold grids. Sections placed on copper grids were double-stained with uranyl acetate and lead citrate according to the Reynolds (1963) procedure. Sections placed on gold grids were treated according to the Thiéry (1967) test to reveal the presence of glycogen. Thus, they were treated in periodic acid (PA), thiocarbohydrazide (TCH) and silver proteinate (SP) as follows: $30 \mathrm{~min}$ in $10 \% \mathrm{PA}$, rinsed in milliQ water, $24 \mathrm{~h}$ in $\mathrm{TCH}$, rinsed in acetic solutions and milliQ water, $30 \mathrm{~min}$ in $1 \% \mathrm{SP}$ in the dark, and rinsed in milliQ water.

The grids were examined in a JEOL 1010 transmission electron microscope operated at $80 \mathrm{kV}$, in the "Centres Científics i Tecnològics de la Universitat de Barcelona (CCiTUB)".

\section{RESULTS}

The observation of a great number of sections of mature spermatozoa of Lecithocladium excisum enabled us to reconstitute its ultrastructural organization and to distinguish three different regions (I-III).

Region I (Figs. 1a-f, 2I) corresponds to the anterior part or premitochondrial area of the spermatozoon. The anterior spermatozoon extremity exhibits only an external ornamentation of the plasma membrane and a few singlets of the first axoneme (Fig. 1a). Soon, the first axoneme appears immediately followed by the second axoneme (Fig. 1b,c). At this level, the external ornamentation of the plasma membrane surrounds only one of the axonemes (Fig. 1c). Areas of region I presenting both axonemes exhibit four attachment zones (Fig. 1c-e). The posterior areas of region I are characterized by an enlarged section (Fig. 1e), the appearance of a small number of cortical microtubules (four elements) located only in one side (Fig. 1e) and a scarce amount of granules of glycogen (Fig. 1f).

Region II (Figs. 1g-i, 2II) is the middle region or mitochondrial area of the spermatozoon. In addition to the structures observed in the posterior part of region I, this region presents a mitochondrion and a higher number of cortical microtubules, up to eight elements coinciding with the greatest size of the mitochondrion (Fig. 1h). Then, the number of cortical microtubules decreases progressively until reaching four elements in the transitional area to region III where the nucleus appears (Fig. 1i).

Region III (Figs. 1j-p, 2III) corresponds to the posterior part or nuclear area of the mature spermatozoon. It is characterized by the disappearance of the mitochondrion, the presence of the nucleus, and the progressive decrease of the number of cortical microtubules (Fig. 1j-m). In this region, the disorganization of the first axoneme occurs (Fig. 11) as well as the disappearance of the nucleus (Fig. $1 \mathrm{~m}, \mathrm{n})$. The posterior extremity of this region exhibits only the second axoneme (Fig. 1n) that disorganizes into doublets and singlets (Fig. 1o,p).

\section{DISCUSSION}

The mature spermatozoon of Lecithocladium excisum shows the basic ultrastructural features described in most digeneans so far: two axonemes of the 9+' 1 ' pattern of trepaxonematans (Ehlers 1984), nucleus, mitochondrion and parallel cortical microtubules (Burton 1972, Jamieson and Daddow 1982, Daddow and Jamieson 1983, Iomini and Justine 1997, Tang et al. 1998, Miquel et al. 2000, Levron et al. 2004a, Seck et al. 2008, Bakhoum et al. 2012, Ndiaye et al. 2012). However, the mature spermatozoon of $L$. excisum differs from those of other digeneans studied until today in several ultrastructural features, such as (i) the presence of a single field of parallel cortical microtubules, (ii) the lack of cortical microtubules in much of the anterior spermatozoon region, (iii) the presence of external ornamentations of the plasma membrane located in the anterior spermatozoon extremity, and (iv) the absence of both spine-like bodies and cytoplasmic expansions.

In the Hemiuroidea, ultrastructural studies on the spermatozoon of members of only three families have been carried out, namely the Didymozoidae Monticelli, 1888 (see Justine and Mattei 1982a, 1983, 1984, Pamplona-

Fig. 1. Consecutive cross-sections of the mature spermatozoon of Lecithocladium excisum from anterior to posterior extremities. $\mathbf{a}-\mathbf{c}-$ cross-sections of the anterior extremity of the spermatozoon showing the ornamented area; $\mathbf{d}-\mathbf{f}-$ cross-sections of the posterior part of the region I showing a progressive increase in the number of cortical microtubules placed in only one side; note the scarce amount of granules of glycogen stained by the method of Thiéry (in f); $\mathbf{g}-\mathbf{i}$ - sections in the region II or mitochondrial area of the 

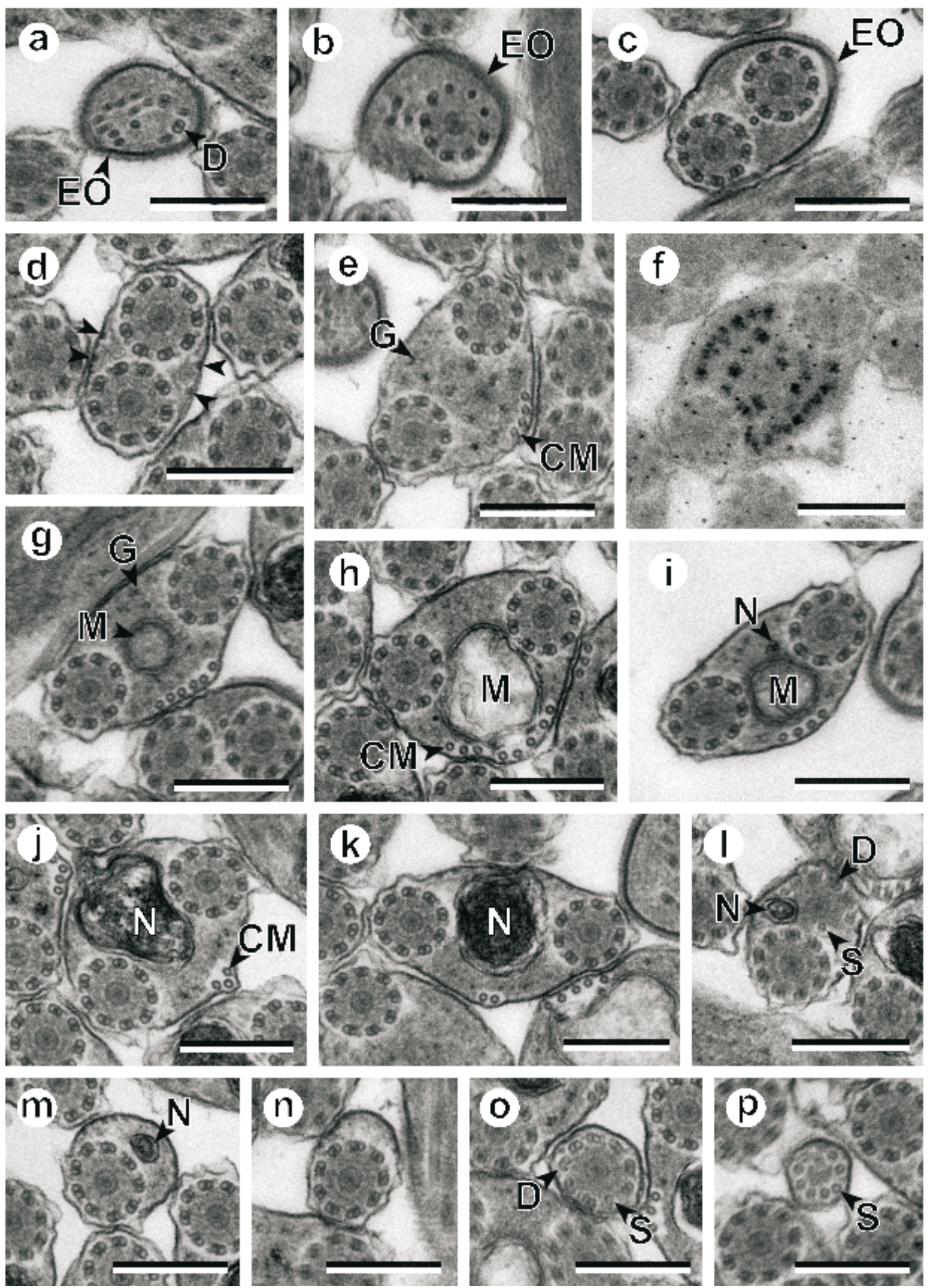

spermatozoon; $\mathbf{j}-\mathbf{p}$ - cross-sections of the region III or posterior part of the spermatozoon from an area containing two axonemes, nucleus and cortical microtubules to the posterior tip exhibiting only singlets of the second axoneme. Abbreviations: $\mathrm{CM}-\mathrm{cortical}$ microtubules; D - doublets; EO - external ornamentation of the plasma membrane; $\mathrm{G}$ - granules of glycogen; $\mathrm{M}$ - mitochondrion; $\mathrm{N}$ - nucleus; $\mathrm{S}$ - singlets. Arrowheads indicate attachment zones. Scale bars: $\mathrm{a}-\mathrm{p}=0.3 \mu \mathrm{m}$. 


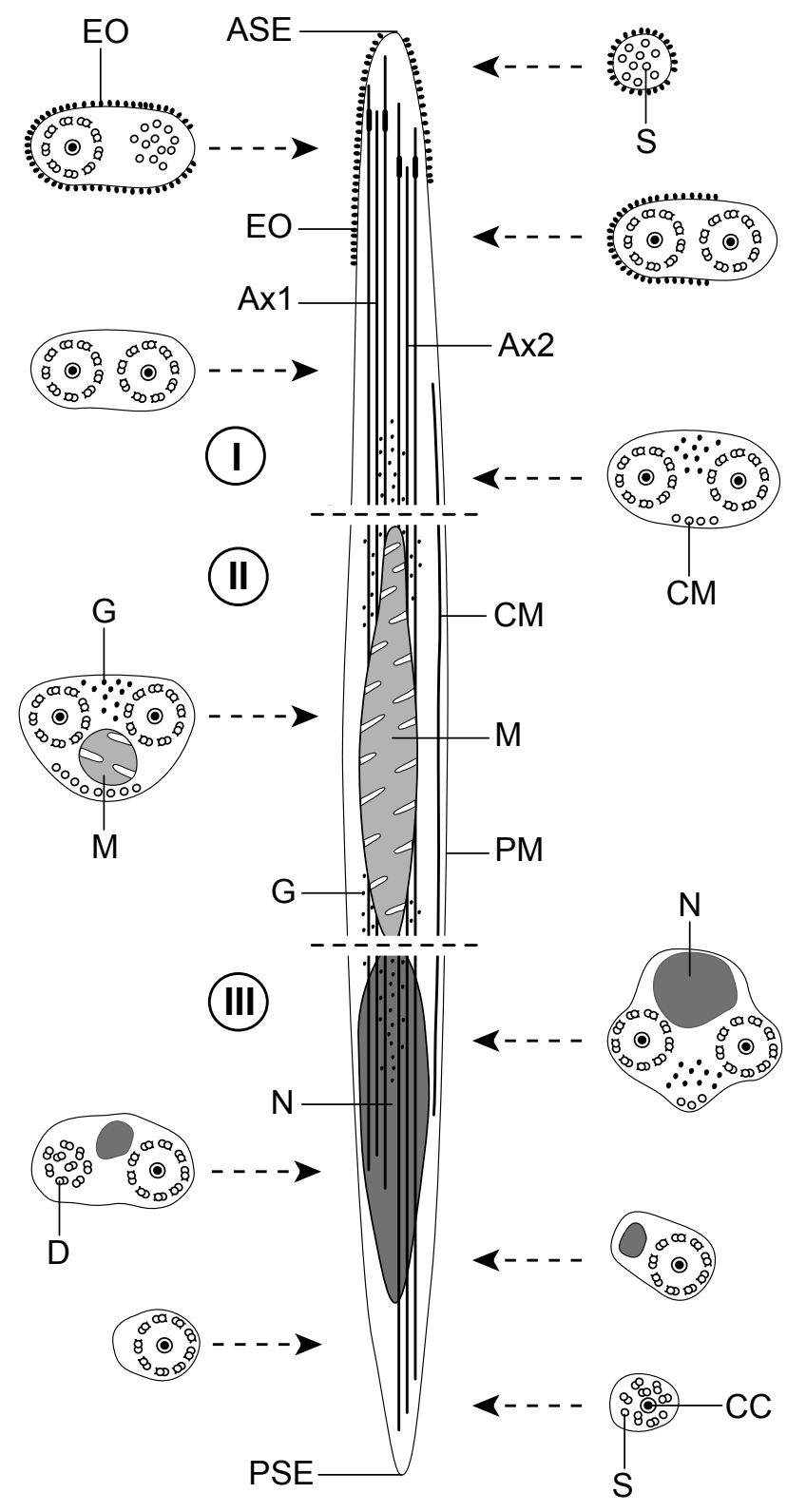

Fig. 2 (I-III). Schematic reconstruction of the mature spermatozoon of Lecithocladium excisum. Abbreviations: ASE - anterior spermatozoon extremity; Ax 1 - first axoneme; Ax 2 - second axoneme; $\mathrm{CC}$ - central core; $\mathrm{CM}$ - cortical microtubules; $\mathrm{D}$ - doublets; EO - external ornamentation of the plasma membrane; $\mathrm{G}$ - granules of glycogen; $\mathrm{M}$ - mitochondrion; $\mathrm{N}$ - nucleus; PM - plasma membrane; PSE - posterior spermatozoon extremity; $\mathrm{S}$ - singlets.

Basilio et al. 2001), Sclerodistomidae Odhner, 1927 (see Justine 1995) and Lecithasteridae Odhner, 1905 (see Quilichini et al. 2010a). With the present study we add data on a fourth family (Hemiuridae). Furthermore, extensive data on the ultrastructure of the spermatozoon are available only for the didymozoid Gonapodasmius sp., the lecithasterid Aponurus laguncula Looss, 1907 and the hemiurid L. excisum (Justine and Mattei 1982a, Quilichini et al. 2010a, present study).
An external ornamentation of the plasma membrane entirely covering the anterior extremity of the spermatozoon as described in L. excisum was previously reported only in two species, namely Gonapodasmius sp. and A. laguncula (Justine and Mattei 1982a, Quilichini et al. 2010a). However, a particularity that exists in the case of both L. excisum and A. laguncula is the absence of cortical microtubules associated with this external ornamentation. This organization has only been observed in Pronoprymna ventricosa (Rudolphi, 1819) (see Quilichini et al. 2007).

Two fields of parallel cortical microtubules are usually described in the spermatozoon of digeneans (Jamieson and Daddow 1982, Justine and Mattei 1982b, Robinson and Halton 1982, Daddow and Jamieson 1983, Cifrian et al. 1993, Iomini and Justine 1997, Miquel et al. 2000, Baptista-Farias et al. 2001, Ndiaye et al. 2002, 2011, Foata et al. 2007, Seck et al. 2008, Bakhoum et al. 2012). Nevertheless, in the case of the hemiuroideans Gonapodasmius sp., A. laguncula and L. excisum, a few cortical microtubules are located only in one side (ventral side) of the spermatozoon (Justine and Mattei 1982a, Quilichini et al. 2010a, present study).

Moreover, there is a particularity in the case of L. excis$u m$ and $A$. laguncula; both species lack cortical microtubules in much of the anterior region of the spermatozoon (Quilichini et al. 2010a, present study). In these species the maximum number of cortical microtubules is present in the mitochondrial region of the spermatozoon: there are ten and eight cortical microtubules in A. laguncula and L. excisum (Quilichini et al. 2010a, present study), respectively.

With respect to Gonapodasmius sp., Justine and Mattei (1982a) described a layer of cortical microtubules associated with the external ornamentation of the plasma membrane in the anterior part of the spermatozoon and a bundle of 20 to 25 cortical microtubules in the middle region. However, in Didymozoon sp. and Didymocystis wedli Ariola, 1902 spermatozoa lacking cortical microtubules were observed (Justine and Mattei 1983, PamplonaBasilio et al. 2001).

Finally, the presence of a single field of cortical microtubules in the microphalloidean $P$. ventricosa should be mentioned (Quilichini et al. 2007). Considering the reported variability of this character, more studies on the superfamily Hemiuroidea and particularly on the unexplored families are necessary in order to elucidate the importance of this character.

Other structures described in most digeneans such as spine-like bodies and cytoplasmic expansions are not present in L. excisum (Miquel et al. 2000, Ndiaye et al. 2002, 2003, 2012, Levron et al. 2004b, Agostini et al. 2005, Seck et al. 2008, Kacem et al. 2010, Bakhoum et al. 2012). It is remarkable that they are also absent from the remaining species of the Hemiuroidea studied to date (Justine and Mattei 1982a, Pamplona-Basilio et al. 2001, Quilichini et al. 2010a). 
The fundamental difference between the spermatozoon of $A$. laguncula and that of $L$. excisum is the type of the posterior extremity. In A. laguncula, Quilichini et al. (2010a) described a well-developed mitochondrion spread through a large part of the posterior end of the spermatozoon and the persistence of both axonemes. In addition, some microtubules from axoneme reach the posterior region of the spermatozoon and disappear just before the posterior tip. Thus, this type of the posterior extremity of the spermatozoon is different than that described in our study of $L$. excisum (without a mitochondrion and presenting only the second axoneme).
Acknowledgements. Authors wish to thank Núria Cortadellas and Almudena García from the "Unitat de Microscòpia, Facultat de Medicina, Centres Científics i Tecnològics de la Universitat de Barcelona (CCiTUB)" for their support in the preparation of samples. Authors also thank Online Access to Research in the Environment (OARE) for facilitating us access to the bibliography. The present study was partly supported by the PCI projects (no. A/023428/09 and no. A/030039/10) of the "Agencia Española de Cooperación Internacional para el Desarrollo (AECID)". A.J.S. Bakhoum benefits from a MAEC-AECID doctoral grant (2010-2011, no. 0000538055).

\section{REFERENCES}

Agostini S., Miquel J., Ndiaye P.I., Marchand B. 2005: Dicrocoelium hospes Looss, 1907 (Digenea, Dicrocoeliidae): spermiogenesis, mature spermatozoon and ultrastructural comparative study. Parasitol. Res. 96: 38-48.

BÂ C.T., Marchand B. 1995: Spermiogenesis, spermatozoa and phyletic affinities in the Cestoda. Mém. Mus. Natl. Hist. Nat. 166: 87-95.

Bakhoum A.J.S., Bâ C.T., Shimalov V.V., Torres J., Miquel J. 2011a: Spermatological characters of the digenean Rubenstrema exasperatum (Rudolphi, 1819) (Plagirochioidea, Omphalometridae). Parasitol. Res. 108: 1283-1293.

Bakhoum A.J.S., Ndiaye P.I., BÂ C.T., Miquel J.: Spermatological characteristics of Elstia stossichianum (Digenea, Mesometridae) from the intestine of the cow bream (Sarpa salpa) off Dakar, Senegal. J. Helminthol. (In press.)

Bakhoum A.J.S., Ndiaye P.I., Sène A., Bâ C.T., Miquel J. 2012: Spermiogenesis and ultrastructure of the spermatozoon of Wardula capitellata (Digenea, Mesometridae), an intestinal parasite of the sparid teleost Sarpa salpa in Senegal. Acta Parasitol. 57: 34-45.

Bakhoum A.J.S., Torres J., Shimalov V.V., BÂ C.T., Miquel J. 2011b: Spermiogenesis and spermatozoon ultrastructure of Diplodiscus subclavatus (Pallas, 1760) (Paramphistomoidea, Diplodiscidae), an intestinal fluke of the pool frog Rana lessonae (Amphibia, Anura). Parasitol. Int. 60: 64-74.

Baptista-Farias M.F.D., Kohn A., Cohen S.C. 2001: Ultrastructure of spermatogenesis and sperm development in Saccocoelioides godoyi Kohn \& Froes, 1986 (Digenea, Haploporidae). Mem. Inst. Oswaldo Cruz 96: 61-70.

BuRTON P.R. 1972: Fine structure of the reproductive system of a frog lung-fluke. III. The spermatozoon and its differentiation. J. Parasitol. 58: 68-83.

Cifrian B., Garcia-Corrales P., Martinez-Alos S. 1993: Ultrastructural study of the spermatogenesis and mature spermatozoa of Dicrocoelium dendriticum (Plathelminthes, Digenea). Parasitol. Res. 79: 204-212.

Daddow L.Y.M., Jamieson B.G.M. 1983: An ultrastructural study of spermiogenesis in Neochasmus sp. (Cryptogonimidae: Digenea: Trematoda). Aust. J. Zool. 31: 1-14.

EhLers U. 1984: Phylogenetisches System der Plathelminthes. Verh. Naturwiss. Ver. Hamburg (NF) 27: 291-294.

Foata J., Quilichini Y., Marchand B. 2007: Spermiogenesis and sperm ultrastructure of Deropristis inflata Molin, 1859 (Digenea, Deropristidae), a parasite of Anguilla anguilla. Parasitol. Res. 101: 843-852.
Gibson D.I. 2002a: Family Hemiuridae Looss, 1899. In: D.I. Gibson, A. Jones and R.A. Bray (Eds.), Keys to the Trematoda. Vol. 1. CABI Publishing, Wallingford and The Natural History Museum, London, UK, pp. 305-340.

Gibson D.I. 2002b: Superfamily Hemiuroidea Looss, 1899. In: D.I. Gibson, A. Jones and R.A. Bray (Eds.), Keys to the Trematoda. Vol. 1. CABI Publishing, Wallingford and The Natural History Museum, London, UK, pp. 299-304.

Hoberg E.P., Mariaux J., Brooks D.R. 2001: Phylogeny among orders of the Eucestoda (Cercomeromorphae): integrating morphology, molecules and total evidence. In: D.T.J. Littlewood and R.A. Bray (Eds.), Interrelationships of the Platyhelminthes. Taylor and Francis, London, UK, pp. 112-126.

Hoberg E.P., Mariaux J., Justine J.-L., Brooks D.R., WeekES P.J. 1997: Phylogeny of the orders of the Eucestoda (Cercomeromorphae) based on comparative morphology: historical perspectives and a new working hypothesis. J. Parasitol. 83: $1128-1147$.

Iomini C., Justine J.-L. 1997: Spermiogenesis and spermatozoon of Echinostoma caproni (Platyhelminthes, Digenea): transmission and scanning electron microscopy, and tubulin immunocytochemistry. Tissue Cell 29: 107-118.

Jamieson B.G.M., Daddow L.M. 1982: The ultrastructure of the spermatozoon of Neochasmus sp. (Cryptogonimidae, Digenea, Trematoda) and its phylogenetic significance. Int. J. Parasitol. 12: $547-559$.

JUSTINE J.-L. 1995: Spermatozoal ultrastructure and phylogeny of the parasitic Platyhelminthes. Mém. Mus. Natl. Hist. Nat. 166: $55-86$.

Justine J.-L. 1998: Spermatozoa as phylogenetic characters for the Eucestoda. J. Parasitol. 84: 385-408.

JuSTINE J.-L. 2001: Spermatozoa as phylogenetic characters for the Platyhelminthes. In: D.T.J. Littlewood and R.A. Bray (Eds.), Interrelationships of the Platyhelminthes. Taylor and Francis, London, UK, pp. 231-238.

Justine J.-L., Mattei X. 1982a: Étude ultrastructurale de la spermiogenèse et du spermatozoïde d'un Plathelminthe: Gonapodasmius (Trematoda: Didymozoidae). J. Ultrastruct. Res. 79: 350-365.

Justine J.-L., Mattei X. 1982b: Réinvestigation de l'ultrastructure du spermatozoïde d'Haematoloechus (Trematoda: Haematoloechidae). J. Ultrastruct. Res. 81: 322-332.

Justine J.-L., Mattei X. 1983: A spermatozoon with two $9+0$ axonemes in a parasitic flatworm, Didymozoon (Digenea: Didymozoidae). J. Submicrosc. Cytol. 15: 1101-1105. 
Justine J.-L., Mattei X. 1984: Ultrastructural observations on the spermatozoon, ovocyte and fertilization process in Gonapodasmius, a gonochoristic trematode (Trematoda: Digenea: Didymozoidae). Acta Zool. (Stockh.) 65: 171-177.

Kacem H., Bakhoum A.J.S., Neifar L., Miquel J. 2010: Spermiogenesis and spermatozoon ultrastructure of the digenean Neoapocreadium chabaudi (Apocreadiidae), a parasite of Balistes capriscus (Pisces, Teleostei). Parasitol. Int. 59: 358366.

Levron C., Miquel J., Oros M., Scholz T. 2010: Spermatozoa of tapeworms (Platyhelminthes, Eucestoda): advances in ultrastructural and phylogenetic studies. Biol. Rev. 85: 523-543.

Levron C., Ternengo S., Marchand B. 2004a: Ultrastructure of spermiogenesis and the spermatozoon of Monorchis parvus Looss, 1902 (Digenea, Monorchiidae), a parasite of Diplodus annularis (Pisces, Teleostei). Parasitol. Res. 93: 102-110.

Levron C., Ternengo S., Marchand B. 2004b: Spermiogenesis and sperm ultrastructure of Poracanthium furcatum (Digenea, Opecoelidae), a parasite of Mullus surmuletus (Pisces, Teleostei). Acta Parasitol. 49: 190-200.

Miquel J., Fournier-Chambrillon C., Fournier P., Torres J. 2006: Spermiogenesis and spermatozoon ultrastructure of the cranial digenean Troglotrema acutum (Leuckart, 1842). J. Parasitol. 92: 441-453.

Miquel J., Nourrisson C., Marchand B. 2000: Ultrastructure of spermiogenesis and the spermatozoon of Opecoeloides furcatus (Trematoda, Digenea, Opecoelidae), a parasite of Mullus barbatus (Pisces, Teleostei). Parasitol. Res. 86: 301-310.

Ndiaye P.I., Miquel J., BÂ C.T., Feliu C., Marchand B. 2002: Spermiogenesis and sperm ultrastructure of Scaphiostomum palaearcticum Mas-Coma, Esteban et Valero, 1986 (Trematoda, Digenea, Brachylaimidae). Acta Parasitol. 47: 259-271.

Ndiaye P.I., Miquel J., Feliu C., Marchand B. 2003: Ultrastructure of spermiogenesis and spermatozoa of Notocotylus neyrai González Castro, 1945 (Digenea, Notocotylidae), intestinal parasite of Microtus agrestis (Rodentia: Arvicolidae) in Spain. Invert. Reprod. Dev. 43: 105-115.

Ndiaye P.I., Quilichini Y., Sène A., Bâ C.T., Marchand B. 2011: Ultrastructure of the spermatozoon of the digenean Cricocephalus albus (Kuhl \& van Hasselt 1822) Looss, 1899 (Platyhelminthes, Pronocephaloidea, Pronocephalidae) parasite of the "hawksbill sea turtle" Eretmochelis imbricata (Linnaeus, 1766) in Senegal. Zool. Anz. 250: 215-222.

Ndiaye P.I., Quilichini Y., Sène A., Tkach V.V., Bâ C.T., MARCHAND B. 2012: Ultrastructural study of the spermatozoon of the digenean Enodiotrema reductum Looss, 1901 (Platy-

Received 14 June 2012 helminthes, Plagiorchioidea, Plagiorchiidae) parasite of the green turtle Chelonia mydas (Linnaeus, 1758) in Senegal. Parasitol. Res. 111: 859-864.

Olson P.D., Littlewood D.T.J., Bray R.A., Mariaux J. 2001: Interrelationships and evolution of the tapeworms (Platyhelminthes: Cestoda). Mol. Phylogenet. Evol. 19: 443-467.

Pamplona-Basilio M.C., Baptista-Farias M.F.D., Kohn A. 2001: Spermatogenesis and spermiogenesis in Didymocystis wedli Ariola, 1902 (Didymozoidae, Digenea). Mem. Inst. Oswaldo Cruz 96: 1153-1159.

Quilichini Y., Foata J., Justine J.-L., Bray R.A., Marchand B. 2010a: Spermatozoon ultrastructure of Aponurus laguncula (Digenea: Lecithasteridae), a parasite of Aluterus monoceros (Pisces, Teleostei). Parasitol. Int. 59: 22-28.

Quilichini Y., Foata J., Justine J.-L., Bray R.A., Marchand B. 2010b: Ultrastructural study of the spermatozoon of Heterolebes maculosus (Digenea, Opistholebetidae), a parasite of the porcupinefish Diodon hystrix (Pisces, Teleostei). Parasitol. Int. 59: 427-434.

Quilichini Y., Foata J., Justine J.-L., Bray R.A., Marchand B. 2011: Spermatozoon ultrastructure of Gyliauchen sp. (Digenea: Gyliauchenidae), an intestinal parasite of Siganus fuscescens (Pisces: Teleostei). Biol. Bull. 221: 197-205.

Quilichini Y., Foata J., Marchand B. 2007: Ultrastructural study of the spermatozoon of Pronoprymna ventricosa (Digenea, Baccigerinae), parasite of the twaite shad Alosa fallax Lacépède (Pisces, Teleostei). Parasitol. Res. 101: 1125-1130.

ReYNOLDS E.S. 1963: The use of lead citrate at high $\mathrm{pH}$ as an electron-opaque stain in electron microscopy. J. Cell Biol. 17: 208-212.

Robinson R.D., HaLton D.W. 1982: Fine structural observations on spermatogenesis in Corrigia vitta (Trematoda: Dicrocoeliidae). Z. Parasitenkd. 68: 53-72.

Seck M.T., Marchand B., BÂ C.T. 2008: Spermiogenesis and sperm ultrastructure of Cotylophoron cotylophorum (Trematoda, Digenea, Paramphistomidae), a parasite of Bos taurus in Senegal. Parasitol. Res. 103: 157-166.

ŚWIDERSKI Z. 1986: Three types of spermiogenesis in cestodes. Proc. 11th Int. Cong. Electron Microsc., Kyoto, pp. 2959-2960.

TANG J., Wang W., Wang G. 1998: Studies on ultrastructure of spermatogenesis and sperm in Pseudorhipidocotyle elpichthys. Acta Hydrobiol. Sin. 22: 168-173.

THIÉRY J.P. 1967: Mise en évidence des polysaccharides sur coupes fines en microscopie électronique. J. Microsc. 6: 987-1018.

Accepted 13 July 2012 